\title{
Neonatal duodenoduodenostomy and missed duodenal stenosis with windsock deformity: a rare intraoperative error of technique and judgement by an unwary surgeon
}

\author{
Ramnik V Patel, ${ }^{1,2}$ Dhaval Govani, ${ }^{3}$ Rasila Patel, ${ }^{4}$ Devendra B Dekiwadia ${ }^{5}$
}

'Department of Paediatric Urology, University College London Hospitals NHS Foundation Trust, London, UK ${ }^{2}$ Department of Paediatric Urology, Great Ormond Street Children Hospital NHS Trust, London, UK

${ }^{3}$ Birmingham Medical School, Birmingham, UK

${ }^{4}$ Department of Alternative Medicine, PGICHR, Rajkot, India

${ }^{5}$ Department of Surgery, PDUMC, Rajkot, India

\section{Correspondence to} Ramnik V Patel, ramnik@doctors.org.uk

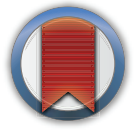 \\ CrossMark}

To cite: Patel RV, Govani $D$, Patel R, et al. BMJ Case Rep Published online: [please include Day Month Year] doi:10.1136/bcr-2013202782

\section{DESCRIPTION}

This is a case of a full-term male infant born by vaginal delivery. Pregnancy was complicated by polyhydramnios and double bubble sign on anomaly but no evidence of Down's syndrome or other associated congenital anomalies. A size 10 nasogastric tube was inserted easily into the stomach without any hold-up and dark green bile of $100 \mathrm{~mL}$ was drained. Anus was normally sited and of normal calibre. A plain abdominal radiograph showed a double bubble sign (figure 1A). The infant underwent exploratory laparotomy and duodenoduodenostomy for presumed duodenal atresia. At operation it was noted that dark green bile was aspirated following opening of the proximal dilated duodenum, which was anastomosed with the distal collapsed duodenum by side-to-side anastomosis. However, the patient continued to have high-bilious aspirates. A paediatric surgical opinion was requested. A careful look at the initial plain film showed few gas bubbles going beyond the distal duodenum into the left side of the abdomen raising doubts about the windsock deformity. A repeat plain radiograph showed dilated stomach and no gas beyond it (figure 1B). An upper gastrointestinal contrast study with delayed $24 \mathrm{~h}$ film failed to show any progression of contrast beyond the mid-duodenum (figure 1C). The patient underwent re-exploration with excision of duodenal web, insertion of nasojejunal transanastomotic feeding tube and recovered uneventfully. Congenital duodenal stenosis can be mucosal diaphragm with a central or eccentric hole, intrinsic muscle wall narrowing or extrinsic narrowing secondary to annular pancreas. ${ }^{1}$ It may pose diagnostic and therapeutic challenges. ${ }^{2}$ Intraoperative errors of technique and judgement may pose serious postoperative problems. ${ }^{3}$

\section{Learning points}

Duodenal stenosis should be suspected if a baby has no chromosomal abnormalities or other associated anomalies and high index of suspicion of windsock deformity leads to early recognition preoperatively.

- Intraoperative bile through the stenotic windsock deformity beyond the site of attachment of the web can mislead the unwary surgeon and the bypass duodenoduodenostomy may entirely remain distal to the obstruction as happened in our case.

- Exceptionally, there could be multiple diaphragms and the downstream one may be missed due to non-dilation and therefore careful passage and withdrawal of balloon Fogarty or Foley catheter both ways proximally into the stomach and distally into the small bowel will prevent both these problems.

Contributors All the authors have made substantial contributions to the conception and design of this paper, the search of literature, the acquisition, analysis and interpretation of the data, to drafting the article or revising it critically for important intellectual content, and to the final approval of the version to be published.
A

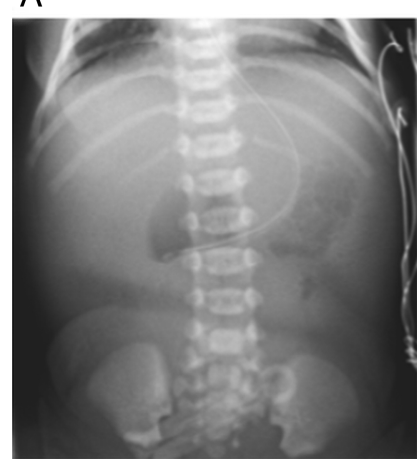

B

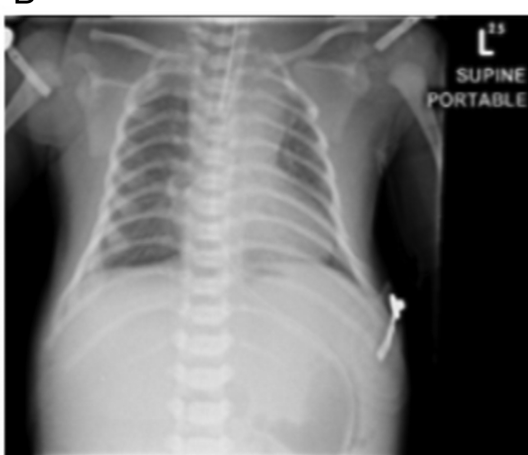

C

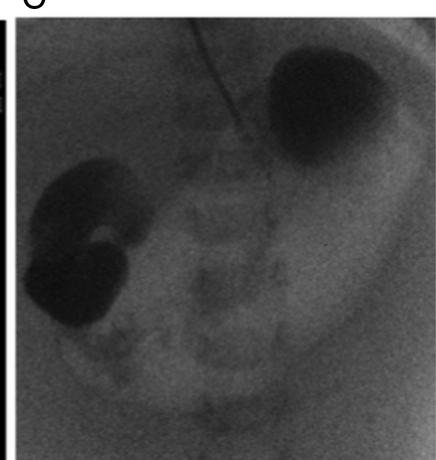

Figure 1 (A) Preoperative radiograph showing double bubble. Note the air beyond the duodenum in the left upper abdomen. (B) Postoperative plain film showing stomach gas only. (C) Upper gastrointestinal delayed contrast film showing no contrast beyond mid-duodenum. 
Competing interests None.

Patient consent Obtained.

Provenance and peer review Not commissioned; externally peer reviewed.

\section{REFERENCES}

1 Patel RV, Kumar H, More B. Preampullary duodenal web simulating gastric outlet obstruction. J Neonatal Surg 2013;2:13.
2 Patel RV, Philip I. Distal duodenal stenosis in Down's syndrome-a rare diagnostic and therapeutic challenge. BMJ Case Rep (in press).

3 Applebaum H, Sydorak R. Duodenal atresia and stenosis-annular pancreas. Chapter 81. In: Coran AG, Caldamone A, Adzick NS, Krummel TM, Laberge JM, Shamberger R. eds Pediatric surgery. 7th edn. Philadelphia, PA: Elsevier Inc, 2012:1051-8.

Copyright 2014 BMJ Publishing Group. All rights reserved. For permission to reuse any of this content visit http://group.bmj.com/group/rights-licensing/permissions.

BMJ Case Report Fellows may re-use this article for personal use and teaching without any further permission.

Become a Fellow of BMJ Case Reports today and you can:

- Submit as many cases as you like

- Enjoy fast sympathetic peer review and rapid publication of accepted articles

- Access all the published articles

- Re-use any of the published material for personal use and teaching without further permission

For information on Institutional Fellowships contact consortiasales@bmjgroup.com

Visit casereports.bmj.com for more articles like this and to become a Fellow 